\title{
Adhesion of Coagulase-negative Staphylococci to Biomaterials
}

\author{
By A. H. HOGT, ${ }^{*}$ J. DANKERT, ${ }^{2}$ J. A. DE VRIES ${ }^{3}$ AND J. FEIJEN ${ }^{1}$ \\ ${ }^{1}$ Department of Chemical Technology, Section of Biomaterials, Twente University of Technology, \\ 'P.O. Box 217, 7500 AE Enschede, The Netherlands \\ ${ }^{2}$ Department of Hospital Epidemiology, University Hospital and ${ }^{3}$ Department of Pediatrics, \\ Division of Pediatric Oncology, University Hospital, Oostersingel 59, 9700 RB Groningen, \\ The Netherlands
}

(Received 3 November 1982; revised 29 April 1983)

The adhesion of two Staphylococcus epidermidis strains and one Staphylococcus saprophyticus strain on to poly(tetrafluorethylene-co-hexafluorpropylene) (FEP)-fluorocarbon and cellulose acetate was studied in vitro. Both $S$. epidermidis strains showed a more hydrophobic character than the encapsulated $S$. saprophyticus as determined by the bacterial affinity towards xylene. Staphylococcus epidermidis showed a significantly higher adhesion on to the hydrophobic FEP than $S$. saprophyticus. The adhesion of staphylococci on to the more hydrophilic cellulose acetate was always low. Treatment of $S$. epidermidis with pepsin or extraction with aqueous phenol yielded cells with a decreased hydrophobicity, which resulted in a decreased adhesion on to FEP. Cells with a decreased hydrophobicity showed a lower rate of reaggregation in suspension. The hydrophobicity and the adhesion on to FEP of $S$. epidermidis were not affected by exposure to a subminimal inhibitory concentration of penicillin. The strong interaction between $S$. epidermidis and FEP, which appeared not to be influenced by the age or the metabolic stage of the bacteria, is mainly caused by hydrophobic bonding.

\section{INTRODUCTION}

The adhesion of bacteria on to mammalian tissue surfaces is recognized as an important initial step in the pathogenesis of an infectious process (Ofek \& Beachey, 1980). Infections associated with prosthetic implants and medical devices might also be preceded by the adhesion of bacteria on these devices. Despite the serious consequences of implant- and device-associated infections, few reports on bacterial adhesion on to biomaterials are available (Holt, 1970; Moore et al., 1980; Locci et al., 1981; Christensen et al., 1982). The micro-organisms most often involved in such infections are coagulase-negative staphylococci (Garvey, 1980). Locci et al. (1981) studied the adhesion of $S$. epidermidis on to various intravenous catheters and indicated that the initial adhesion occurred in irregularities along the otherwise smooth catheter surface from which micro- and macrocolonies developed. Slime-producing staphylococci adhering to such catheters obtained from patients with intravascular catheter-associated infections were cemented in a matrix of unidentified amorphous material, whereas non-slime-producing staphylococci adhered as individual cells not encased in an adhesive layer (Christensen et al., 1982).

We have studied in vitro the adhesion of three strains of coagulase-negative staphylococci on to two different biomaterials. The materials tested were poly(tetrafluorethylene-co-hexafluorpropylene) (FEP), a hydrophobic material used in vascular grafts, intravenous catheters and trachea prostheses, and cellulose acetate (CA), a more hydrophilic material used for the coating of sorbents in haemoperfusion systems.

\footnotetext{
Abbreviations: CA, cellulose acetate; DPCC, diphenylcarbamyl chloride; FEP, poly(tetrafluorethylene-cohexafluorpropylene); LTA, lipoteichoic acid; MIC, minimum inhibitory concentration; TLCK, $N$ - $\alpha-p$-tosyl-Llysine chloromethyl ketone; TSB, trypticase soy broth.
} 


\section{METHODS}

Bacterial strains and growth conditions. Two strains of Staphylococcus epidermidis and one strain of Staphylococcus saprophyticus were used. Staphylococcus epidermidis strain 1 was cultured from blood samples collected from a child with bacteraemia and the other $S$. epidermidis strain 2 was isolated from a bottle containing an intravenous fluid. Staphylococcus saprophyticus was isolated from the bed of a surgical patient nursed in the Intensive Care Unit. Micro-organisms were Gram-positive cocci in clusters and were coagulase-negative when tested by the slide and the tube test using rabbit plasma (Sylvana, Grand Island, N.Y., U.S.A.). Each strain was further characterized using the API Staph gallery (API System S.A., Montalieu Vercieu, France). Strains 1 and 2, coded as 6706113 were identified as $S$. epidermidis. Strain 3, coded as 6630112 was identified as $S$. saprophyticus. Both $S$. epidermidis strains were sensitive and $S$. saprophyticus was moderately sensitive to lysostaphin (Sigma) (Kloos \& Schleifer, 1975). All three staphylococcal strains were oxidase-negative (Faller \& Schleifer, 1981). The S. saprophyticus strain was encapsulated, as demonstrated by the India ink wet-film method (Duguid, 1951) and by the Muir method (Cowan \& Steel, 1974), whereas neither $S$. epidermidis strain was encapsulated or produced slime when tested according to the method of Christensen et al. (1982).

Bacteria were grown for $18 \mathrm{~h}$ at $37^{\circ} \mathrm{C}$ in $50 \mathrm{ml}$ Trypticase Soy Broth (TSB; BBL) in a rotary shaker (New Brunswick Scientific Co.) at 120 r.p.m. Late-exponential phase cells were obtained by culturing $2 \mathrm{ml}$ of the overnight culture in $100 \mathrm{ml}$ fresh TSB at $37^{\circ} \mathrm{C}$ for $4.5 \mathrm{~h}$; stationary phase cells were obtained by incubating for $18 \mathrm{~h}$. Cells were harvested by centrifugation (Beckman Instruments Inc., model J2-21) at $20000 \mathrm{~g}$ for $10 \mathrm{~min}$ at $4^{\circ} \mathrm{C}$, washed three times with $60 \mathrm{ml}$ amounts of $\mathrm{NaCl} /$ phosphate buffer $(0 \cdot 1 \mathrm{M}-\mathrm{NaCl}$ and $13 \mathrm{~mm}$-phosphate buffer, $\mathrm{pH} \mathrm{7.2)} \mathrm{and} \mathrm{resuspended} \mathrm{in} 60 \mathrm{ml}$ of the same buffer. Clusters of bacteria were dispersed by aspirating and expelling each suspension twice through a sterile 25 gauge steel needle attached to a syringe (B-D Plastipak, Dublin, Ireland). Then the suspension was filtered through a membrane filter (type SC, pore size $8 \mu \mathrm{m}$; Millipore). Microscopic examinations on wet mounts of the filtered suspensions showed that the suspensions primarily contained single cells. The optical density of the suspensions was measured at $540 \mathrm{~nm}$ (model 24 spectrophotometer, Beckman Instruments Inc.). The number of viable colony forming units was determined by spreading $0.1 \mathrm{ml}$ portions from serial tenfold dilutions of bacterial suspensions in TSB on to blood agar plates (Oxoid). After incubation at $37^{\circ} \mathrm{C}$ for $18 \mathrm{~h}$, the numbers of colonies were counted. Bacterial suspensions in $\mathrm{NaCl} /$ phosphate buffer were adjusted to an OD of 1.0 and contained approximately $10^{9} \mathrm{c} . \mathrm{f} . \mathrm{u} . \mathrm{ml}^{-1}$.

In order to measure the reaggregation of bacteria, $3 \mathrm{ml}$ of the bacterial suspensions in $\mathrm{NaCl} /$ phosphate buffer were sealed in spectrophotometer tubes $(45 \times 10 \times 10 \mathrm{~mm}$, Thovadec Hospidex, Nieuwkoop, the Netherlands) and incubated in a rotary shaker incubator $\left(120\right.$ r.p.m., $\left.37^{\circ} \mathrm{C}\right)$. Optical densities of the suspensions were measured at $540 \mathrm{~nm}$ at various time intervals up to $2 \cdot 5 \mathrm{~h}$.

Bacterial cell surface hydrophobicity. The cell surface hydrophobicity of the bacteria was measured using the method described by Rosenberg et al. (1980). To round-bottom test tubes (10 $\mathrm{mm}$ inner diameter) containing washed cells suspended in $3 \mathrm{ml} \mathrm{NaCl} /$ phosphate buffer and adjusted to an $\mathrm{OD}$ of approximately $1 \cdot 0$, various volumes of $p$-xylene (Brocades, Maarssen, the Netherlands) ranging from 0 to $0.5 \mathrm{ml}$ were added. The mixtures were vigorously agitated for $60 \mathrm{~s}$ using a Whirlimixer (Cenco, Breda, the Netherlands). After $20 \mathrm{~min}$, the aqueous phase was removed with a Pasteur pipette and transferred to a $4.5 \mathrm{ml}$ cuvette. The OD was measured at $540 \mathrm{~nm}$. The fractional decrease in OD of the bacterial suspensions was determined as a function of the xylene volume added.

Polymer films. Films of FEP and CA were used for determining the bacterial interaction with a hydrophobic surface and a non-hydrophobic surface, respectively. Cellulose acetate, type 'TV 20' was purchased from Fabelta S.A., Tubize, Belgium; the degree of substitution was $2.49(40 \cdot 1 \%$ acetyl), the number average molecular weight $\left(\bar{M}_{\mathrm{n}}\right)$ was 53000 . Films of CA were prepared as follows: CA $(10 \mathrm{~g})$ was dissolved in acetone $(350 \mathrm{ml})$, the solution was membrane filtered (Type LS, pore size $5 \mu \mathrm{m}$; Millipore) and concentrated under reduced pressure to a residual weight of approximately $100 \mathrm{~g}$. The solution was cast on a glass plate $(70 \times 17 \mathrm{~cm})$ and subsequently dried by exposure to a low flow of nitrogen gas for $18 \mathrm{~h}$ at room temperature. The film was detached from the glass surface by immersion in water and then dried at room temperature. Circular specimens ( $34 \mathrm{~mm}$ diameter) were cut from the films with a dinting punch, rinsed with distilled water and dried at room temperature. After sterilization by $\gamma$ irradiation (2.5 Mrad, Gammaster, Ede, the Netherlands) contact angle measurements were made using a sessile drop (water) technique (Adamson, 1976). After a contact time of $30 \mathrm{~s}$, the water contact angle on CA was $63^{\circ} \pm 5^{\circ}$ (mean value \pm S.D. of ten measurements). Differential scanning calorimetry (DSC-2, Perkin Elmer, Norwalk, Conn., U.S.A.) studies revealed no crystallinity in the CA films.

Circular specimens of FEP were obtained from a sheet of FEP-fluorocarbon, type ' 500 A' (Du Pont de Nemours, Geneva, Switzerland). The specimens were ultrasonically cleaned ( $50 \mathrm{KHz}$, Bransonic 221 , Branson B.V., Soest, the Netherlands) in a $1 \%(\mathrm{v} / \mathrm{v})$ detergent solution (RBS 25 , Hicol, Rotterdam, the Netherlands) for $30 \mathrm{~min}$, followed by extensive rinsing with distilled water, ethanol and diethyl ether. The FEP specimens were sterilized by dry heat for $3 \mathrm{~h}$ at $175^{\circ} \mathrm{C}$. The FEP water contact angle was determined to be $108^{\circ} \pm 2^{\circ}$ (mean value \pm S.D. of ten measurements). 
In order to determine that the two polymer films were not contaminated with bacterial lipopolysaccharide, specimens $\left(10 \mathrm{~mm}^{2}\right)$ obtained before sterilization were incubated at $37^{\circ} \mathrm{C}$ in $0.1 \mathrm{ml}$ pyrogen-free physiological saline with $0.1 \mathrm{ml}$ Limulus lysate preparation (Limulus amebocyte lysate, Mallinckrodt, Inc., St Louis, Mo., U.S.A.). No gelation reaction was observed after $1 \mathrm{~h}$. As a positive control the test was performed on specimens contaminated with $0.1 \mathrm{ml}$ of a standard Escherichia coli endotoxin preparation ( $50 \mathrm{pg} \mathrm{ml}^{-1}$, Mallinckrodt).

Bacterial adhesion and desorption. Circular specimens of the two polymer films were placed into the wells of polystyrene culture dishes (six-well, $35 \mathrm{~mm}$ inner diameter, Costar, Cambridge, Mass., U.S.A.), fixed to the bottoms with glass rings ( $30 \mathrm{~mm}$ inner diameter) and rinsed with $\mathrm{NaCl} /$ phosphate buffer $(3 \mathrm{ml})$. After the addition of $3 \mathrm{ml}$ bacterial suspension ( $\mathrm{NaCl} /$ phosphate buffer), films were incubated at $37^{\circ} \mathrm{C}$ in a rotary shaker $(120 \mathrm{r} . \mathrm{p} . \mathrm{m}$.) for $2.5 \mathrm{~h}$. The films were then rinsed eight times with $3 \mathrm{ml}$ amounts of $\mathrm{NaCl} / \mathrm{phosphate}$ buffer and treated with $4 \%$ $(\mathrm{w} / \mathrm{v})$ glutaraldehyde in $\mathrm{NaCl} / \mathrm{phosphate}$ buffer to fix adhering bacteria. The films were finally rinsed with distilled water and dried at room temperature. Adhering bacteria were counted by bright-field microscopy (Olympus BHB/PM-10M, Olympus Optical Co. Ltd, Tokyo, Japan). The number of adhering bacteria per $\mathrm{mm}^{2}$ of the films was determined by examining six $0.05 \mathrm{~mm}^{2}$ areas on each film. When aggregates of bacteria were observed, each aggregate was considered to be one unit. All experiments were performed in duplicate.

To study the influence of $\mathrm{pH}$ on the bacterial adhesion, bacteria were suspended in either $\mathrm{NaCl} /$ citrate buffer $(0.1 \mathrm{M}-\mathrm{NaCl}$ and $0.1 \mathrm{M}$-citrate, $\mathrm{pH} 3 \cdot 0), \mathrm{NaCl} /$ acetate buffer $(0.1 \mathrm{M}-\mathrm{NaCl}$ and $0.1 \mathrm{M}$-acetate, $\mathrm{pH} 5 \cdot 0), \mathrm{NaCl} /$ phosphate buffer $(0 \cdot 1 \mathrm{M}-\mathrm{NaCl}$ and $0 \cdot 1 \mathrm{M}$-phosphate, $\mathrm{pH} 7 \cdot 2)$, or $\mathrm{NaCl} /$ carbonate buffer $(0 \cdot 1 \mathrm{M}-\mathrm{NaCl}$ and $0 \cdot 1 \mathrm{M}-$ carbonate, pH 9.4). In some experiments, 20 mM-EDTA (disodium salt, Merck) was added to the bacterial suspension.

To study the desorption of adhering bacteria, polymer films were exposed for $2.5 \mathrm{~h}$ to suspensions containing either $S$. epidermidis strain 1 or $S$. saprophyticus with approximately $5 \times 10^{8}$ cells $\mathrm{ml}^{-1}$, followed by one, eight or sixteen rinses with $3 \mathrm{ml}$ amounts of $\mathrm{NaCl} /$ phosphate buffer. The effect of proteolytic enzymes or a chelating agent on desorption was studied as follows. FEP films, exposed for $2.5 \mathrm{~h}$ to a $S$. epidermidis strain 1 suspension

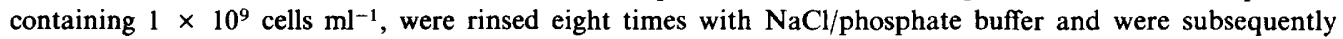
incubated for $1.5 \mathrm{~h}$ at $37^{\circ} \mathrm{C}$ in $\mathrm{NaCl} /$ phosphate buffer $(0 \cdot 1 \mathrm{M}-\mathrm{NaCl}$ and $0 \cdot 1 \mathrm{M}$-phosphate, $\mathrm{pH} 8 \cdot 0)$ containing $0 \cdot 1 \%$ (w/v) trypsin (type XI, DPCC-treated; Sigma) or $0 \cdot 1 \%(w / v) \alpha$-chymotrypsin (type VII, TLCK-treated; Sigma), or in $\mathrm{NaCl} /$ citrate buffer (pH 3.0) containing $0 \cdot 1 \%(\mathrm{w} / \mathrm{v})$ pepsin (Sigma), or in $\mathrm{NaCl} /$ phosphate buffer containing 20 mM-EDTA. After the treatments, the films were washed three times with $\mathrm{NaCl} /$ phosphate buffer. The adhering bacteria were fixed with glutaraldehyde and counted as described above.

Pretreatment of bacteria. The following methods were used to determine the effect of $\mathrm{pH}$, bacterial viability, proteolytic enzymes, a low concentration of penicillin and extraction with aqueous phenol on bacterial reaggregation, cell surface hydrophobicity and adhesion.

To study the influence of $\mathrm{pH}$, bacteria were suspended in buffer solutions as described above.

To obtain non-viable bacteria, bacterial suspensions in $\mathrm{NaCl} /$ phosphate buffer containing $10^{9}$ to $10^{10} \mathrm{cells}^{-1}$ were placed in a waterbath at $60^{\circ} \mathrm{C}$ for $1 \mathrm{~h}$ or incubated in $2 \%(\mathrm{v} / \mathrm{v})$ formaldehyde at room temperature for $1 \mathrm{~h}$. The bacteria were then sedimented by centrifugation and washed three times with $\mathrm{NaCl} / \mathrm{phosphate}$ buffer. Samples cultured from either the heat- or formaldehyde-treated bacterial suspensions showed no growth after $48 \mathrm{~h}$.

Exponential phase bacterial cells were incubated for $1.5 \mathrm{~h}$ at $37^{\circ} \mathrm{C}$ in suspensions containing trypsin, chymotrypsin or pepsin as described above. The suspensions were then chilled rapidly, centrifuged $\left(10000 \mathrm{~g}, 4^{\circ} \mathrm{C}\right.$, $10 \mathrm{~min}$ ) and the bacteria were washed three times with ice-cold $\mathrm{NaCl} /$ phosphate buffer $(\mathrm{pH} \mathrm{7.2)}$. In some experiments $20 \mathrm{mM}$-EDTA was added to the bacterial suspension.

Lipoteichoic acid (LTA)-deficient bacteria were obtained using two methods. Firstly, the minimal inhibitory concentration (MIC) of penicillin for both $S$. epidermidis strains was determined by the standard serial twofold dilution technique. The MIC of strain 1 and strain 2 were $7.5 \mathrm{U} \mathrm{ml}^{-1}$ and $0.02 \mathrm{U} \mathrm{ml}^{-1}$, respectively. Bacteria were then cultured in TSB containing a subminimal inhibitory concentration of penicillin ( $0.25 \mathrm{MIC})$ to stimulate the release of LTA (Alkan \& Beachey, 1978). Bacteria were harvested after $4.5 \mathrm{~h}$ incubation at $37^{\circ} \mathrm{C}$ and washed as usual. For the second method, bacteria grown in TSB overnight, centrifuged $\left(10000 \mathrm{~g}, 4{ }^{\circ} \mathrm{C}, 10 \mathrm{~min}\right)$ and washed with distilled water, were extracted using the hot $\left(65-68^{\circ} \mathrm{C}\right.$ ) aqueous phenol method (Westphal et al., 1952; Wicken et al., 1973) modified according to Kessler \& Shockman (1979) by the addition of $10 \mathrm{mM}-\mathrm{MgCl}_{2}$ to the aqueous phase. Cells harvested by centrifugation $\left(10000 \mathrm{~g}, 4^{\circ} \mathrm{C}, 10 \mathrm{~min}\right)$ were finally washed three times with $\mathrm{NaCl} /$ phosphate buffer.

In order to obtain decapsulated $S$. saprophyticus, cells were either grown in TSB at $20^{\circ} \mathrm{C}$ or $42^{\circ} \mathrm{C}$ for $48 \mathrm{~h}$, or were mechanically agitated in $\mathrm{NaCl} /$ phosphate buffer at $40^{\circ} \mathrm{C}$ for $5 \mathrm{~min}$ (Stinson \& Van Oss, 1971).

Preparation of crude lipoteichoic acid. A crude LTA preparation, obtained using the hot aqueous phenol extraction method (Westphal et al., 1952; Wicken et al., 1973) modified according to Kessler \& Shockman (1979) was dialysed against demineralized water at $4{ }^{\circ} \mathrm{C}$ for $48 \mathrm{~h}$. Desoxyribonuclease (type I, Merck), and ribonuclease (Merck) were added to digest polynucleotides prior to further dialysis at $4^{\circ} \mathrm{C}$ for $15 \mathrm{~h}$. The crude LTA was 


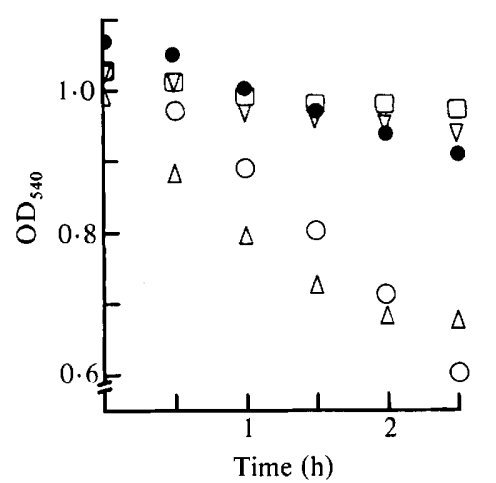

Fig. 1. Optical densities of bacterial suspensions as a function of time. Staphylococcus epidermidis strain $1(\mathrm{O})$ and $S$. saprophyticus (O) suspensions were prepared from bacteria grown in TSB at $37^{\circ} \mathrm{C}$ for $4.5 \mathrm{~h}$. Bacteria were washed, and suspended in $\mathrm{NaCl} /$ phosphate buffer, $\mathrm{pH} 7 \cdot 2$, and filtered through a membrane filter (pore size $8 \mu \mathrm{m}$ ). Staphylococcus epidermidis strain 1 was pretreated with pepsin ( $\square$ ) and strain 2 with hot aqueous phenol ( $\nabla)$. Staphylococcus epidermidis strain 1 was also suspended in 20 mM-EDTA $(\triangle)$

concentrated using a rotary evaporator (model RV 4, Bühler, Tübingen, Germany), lyophilized (Edwards, Crawley, Sussex) and stored at $4^{\circ} \mathrm{C}$.

The crude LTA was added to suspensions of bacteria in $\mathrm{NaCl} / \mathrm{phosphate}$ buffer to a final concentration of $0.5 \%$ (w/v). Films of FEP were treated with solutions of crude LTA in NaCl/phosphate buffer $\left(1 \mathrm{mg} \mathrm{ml}^{-1}\right)$ for $1 \mathrm{~h}$ at room temperature. The films were then rinsed carefully with buffer for $15 \mathrm{~min}$ avoiding air contact with the polymer surfaces. Contact angles for these specimens were $104^{\circ} \pm 2^{\circ}$ (mean \pm S.D. of ten measurements).

Statistical methods. For calculations of $P$ values the Student's $t$-test of significance between two sample means was used (Fisher \& Yates, 1957).

\section{RESULTS}

\section{Reaggregation of bacteria}

Optical density values of $S$. epidermidis suspensions decreased at a higher rate than those of $S$. saprophyticus (Fig. 1). Plots of the decrease in OD of $S$. epidermidis strain 1 suspensions were similar for $\mathrm{pH}$ values ranging from 5.0 to 9.4 . However, in $\mathrm{NaCl} /$ citrate buffer, $\mathrm{pH} \mathrm{3.0,S}$. epidermidis rapidly reaggregated to macroscopic clusters. Suspensions prepared from $S$. epidermidis cells extracted with aqueous phenol or treated with pepsin showed only a minimal decrease in OD (Fig. 1). The OD plots of suspensions containing bacteria treated with trypsin or chymotrypsin, or grown in TSB containing $0.25 \mathrm{MIC}$ of penicillin were similar to those of nontreated bacteria grown in TSB. An initial decrease in OD which levelled out after approximately $1.5 \mathrm{~h}$ was observed when EDTA was added to the bacterial suspension (Fig. 1).

\section{Bacterial cell surface hydrophobicity}

The affinities of the three staphylococcal strains towards xylene are presented in Fig. 2. Both $S$. epidermidis strains, but not $S$. saprophyticus, exhibited high affinity towards xylene (Fig. $2 a$ ). Treatment of both $S$. epidermidis strains with pepsin resulted in a substantially decreased xylene affinity, whereas trypsin or chymotrypsin had no effect (Fig. 2b). The cell surface

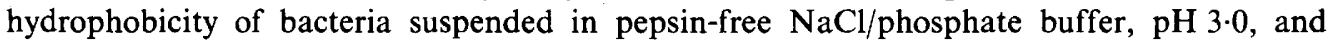
subsequently resuspended in $\mathrm{NaCl} /$ phosphate buffer, $\mathrm{pH} 7 \cdot 2$, was unchanged. Extraction with aqueous phenol was performed using $S$. epidermidis strain 2 . The extracted cells showed a decreased affinity towards xylene. Adding $0.5 \%(\mathrm{w} / \mathrm{v})$ crude LTA to a $S$. epidermidis suspension also decreased the xylene affinity of the bacteria (Fig. 2c). Bacteria grown in TSB containing $0.25 \mathrm{MIC}$ of penicillin showed the same affinity as non-treated bacteria. 

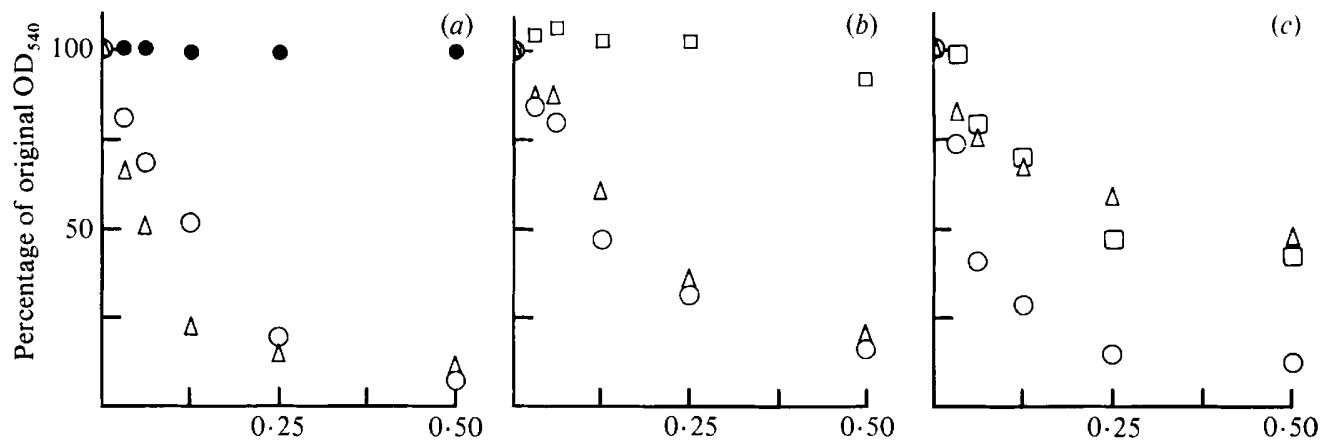

Amount of xylene added $(\mathrm{ml})$

Fig. 2. Fractional decrease of optical density of bacterial suspensions as a function of xylene volume added according to Rosenberg $e t$ al. (1980). Optical density was measured spectrophotometrically at $540 \mathrm{~nm}$ using $\mathrm{NaCl} /$ phosphate buffer suspensions of : (a) S. epidermidis strain $1(\mathrm{O})$, strain $2(\triangle)$, and $S$. saprophyticus $(O) ;(b) S$. epidermidis strain 1 pretreated with trypsin $(O)$, chymotrypsin $(\triangle)$ or pepsin $(\square)$; and (c) $S$. epidermidis strain 2 grown in TSB with a subminimal inhibitory concentration of penicillin (O), extracted with hot aqueous phenol according to Westphal et al. (1952) and Wicken et al. $(1973)(\triangle)$, or $S$. epidermidis strain 2 containing $0.5 \%(w / v)$ crude lipoteichoic acid obtained from an aqueous phenol extract of $S$. epidermidis strain $2(\square)$.

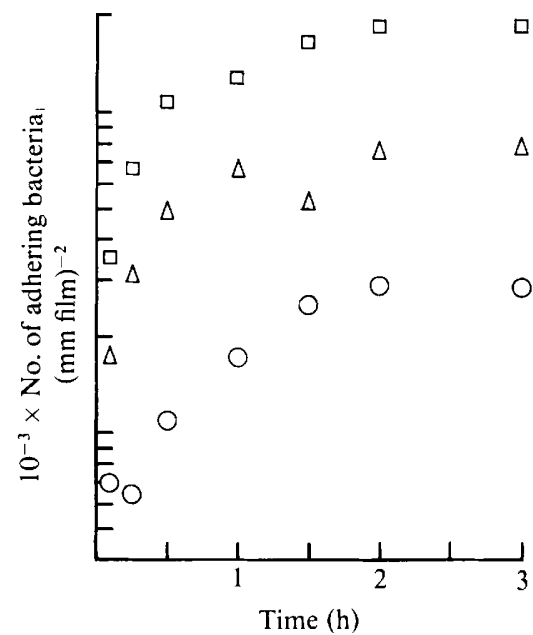

Fig. 3. Numbers of bacteria adhering on to FEP-fluorocarbon as a function of exposure time. Specimens of the films were incubated with suspensions of $S$. epidermidis strain 1 in $\mathrm{NaCl} / \mathrm{phosphate}$ buffer containing $1 \times 10^{7}(\mathrm{O}), 5 \times 10^{7}(\triangle)$, or $1 \times 10^{8}(\square)$ cells $\mathrm{ml}^{-1}$ at $37^{\circ} \mathrm{C}$ for various time intervals up to $3 \mathrm{~h}$. The polymer films were then rinsed eight times with $3 \mathrm{ml}$ amounts of buffer (see Methods).

\section{Adhesion of bacteria}

Higher numbers of $S$. epidermidis strain 1 adhered on to FEP when exposure times were prolonged and when the initial cell concentration was increased (Fig. 3). Saturation coverage of $S$. epidermidis was always reached after $2 \mathrm{~h}$ exposure time with bacterial cell concentrations of $10^{7}$ cells $\mathrm{ml}^{-1}$ or more. In all further experiments an exposure time of $2.5 \mathrm{~h}$ was used. Exponential phase bacteria adhered in the same number as stationary phase bacteria. In further experiments exponential phase bacteria were used. Similar numbers of $S$. epidermidis adhered on to FEP at $\mathrm{pH}$ values of $5 \cdot 0,7 \cdot 2$ and $9 \cdot 4$. Adhesion of $S$. epidermidis strain 1 on to CA was much less than on to FEP (Fig. $4 a$ ). The numbers of this micro-organism adhering on to polymer films appeared to be dependent on the initial bacterial cell concentrations, in contrast to the numbers of adhering $S$. saprophyticus (Fig. $4 b$ ). 


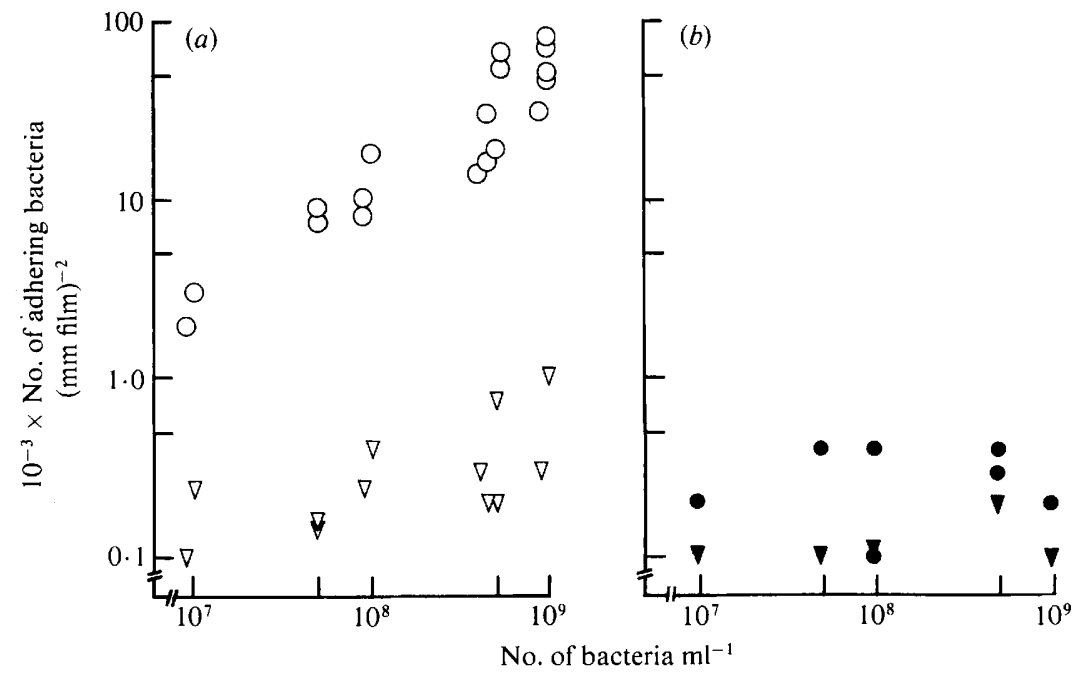

Fig. 4. Numbers of adhering bacteria found on FEP-fluorcarbon and CA films. Specimens of the films were incubated with various concentrations of bacteria suspended in $\mathrm{NaCl} /$ phosphate buffer for $2.5 \mathrm{~h}$ at $37^{\circ} \mathrm{C}$. The polymer films were then rinsed eight times with $3 \mathrm{ml}$ amounts of buffer (see Methods). Each point in the graphs represents a mean value obtained from duplicate experiments. (a) Staphylococcus epidermidis strain 1 on FEP $(O)$ and on CA $(\nabla) ;(b) S$. saprophyticus on FEP $(O)$ and on CA ( $)$.

Table 1. Effect of pretreatment of S. epidermidis (strain I) and S. saprophyticus on adhesion on to FEP-fluorocarbon

Specimens of the polymer films were incubated with bacterial suspensions in $\mathrm{NaCl} /$ phosphate buffer, containing $5 \times 10^{8}$ or $1 \times 10^{9}$ cells $\mathrm{ml}^{-1}$ for $2.5 \mathrm{~h}$ at $37^{\circ} \mathrm{C}$ and rinsed eight times with $3 \mathrm{ml}$ amounts of buffer. Further details on pretreatment of bacteria are given in Methods.

\begin{tabular}{|c|c|c|c|c|}
\hline \multirow{2}{*}{$\begin{array}{l}10^{-9} \times \text { Initial concn } \\
\text { of bacteria } \\
\text { incubated with film } \\
\left(\mathrm{ml}^{-1}\right)\end{array}$} & \multicolumn{4}{|c|}{$10^{-3} \times$ No. of adhering bacteria $(\mathrm{mm} \text { FEP film })^{-2} \pm \mathrm{s}}$. \\
\hline & $\begin{array}{l}\text { Pretreatment } \\
\text { of bacteria }\end{array}$ & $\begin{array}{l}\text { S. epidermidis } \\
\text { strain } 1\end{array}$ & $\begin{array}{l}\text { S. epidermidis } \\
\text { strain } 2\end{array}$ & S. saprophyticus \\
\hline 0.5 & None & $16 \pm 1$ & ND & $0 \cdot 3 \pm 0.1$ \\
\hline 0.5 & Heat $\left(60^{\circ} \mathrm{C}\right)$ & $14 \pm 7$ & ND & $0.4 \pm 0.2$ \\
\hline $0 \cdot 5$ & Formaldehyde $(2 \%, \mathrm{w} / \mathrm{v})$ & $17 \pm 2$ & ND & $0 \cdot 3 \pm 0 \cdot 1$ \\
\hline $1 \cdot 0$ & None & $52 \pm 17$ & $46 \pm 8$ & $0.3 \pm 0.1$ \\
\hline $1 \cdot 0$ & Trypsin $(0 \cdot 1 \%, w / v)$ & $68 \pm 8$ & $42 \pm 4$ & $0 \cdot 2 \pm 0.1$ \\
\hline $1 \cdot 0$ & Chymotrypsin $(0 \cdot 1 \%, \mathrm{w} / \mathrm{v})$ & $47 \pm 6$ & $45 \pm 6$ & $0.3 \pm 0.2$ \\
\hline $1 \cdot 0$ & Pepsin $(0.1 \%, \mathrm{w} / \mathrm{v})$ & $1 \cdot 4 \pm 0 \cdot 3^{*}$ & $11 \pm 7^{*}$ & $0 \cdot 6 \pm 0 \cdot 6$ \\
\hline
\end{tabular}

ND, Not determined.

* Significant $(P<0.001)$ difference between control and test. Other differences were not significant $(P>0 \cdot 1)$.

\section{Effect of pretreatment of bacteria on adhesion}

Heat-killed or formaldehyde-fixed $S$. epidermidis strain 1 and $S$. saprophyticus adhered on to both polymer films to the same extent as the viable bacteria. No significant differences in the adhesion of the $S$. epidermidis strains and $S$. saprophyticus on to FEP were observed between trypsin- or chymotrypsin-treated cells and non-treated cells. Pepsin-pretreatment of $S$. epidermidis strongly reduced their adhesion on to FEP as compared to non-treated bacteria (Table 1). The presence of EDTA in the suspension during the adhesion test did not affect bacterial adhesion on to FEP (result not shown). Staphylococcus saprophyticus cells, either mechanically agitated in warm saline (Stinson \& Van Oss, 1970), or grown at $20^{\circ} \mathrm{C}$ or $42^{\circ} \mathrm{C}$ in 
Table 2. Lipoteichoic acid-related effects on the adhesion of $S$. epidermidis (strain 2) on to FEP-fluorocarbon and $C A$

The polymer films were incubated for $2.5 \mathrm{~h}$ at $37^{\circ} \mathrm{C}$ with $\mathrm{NaCl} /$ phosphate suspensions containing $1 \times$ $10^{9}$ cells of $S$. epidermidis strain $2 \mathrm{ml}^{-1}$, which were either non-treated, exposed to $0 \cdot 25 \mathrm{MIC}$ penicillin, or treated with hot aqueous phenol. Crude LTA was added to the bacterial suspensions in a final concentration of $0.5 \%(\mathrm{w} / \mathrm{v})$. The polymer films were preincubated with crude LTA in $\mathrm{NaCl} / \mathrm{phosphate}$ buffer $\left(1 \mathrm{mg} \mathrm{ml}^{-1}\right)$ for $1 \mathrm{~h}$ at room temperature. Further details are given in Methods.

Experimental conditions

Control

Bacteria exposed to $0.25 \mathrm{MIC}$

of penicillin

Bacteria treated with hot

aqueous phenol

Bacterial suspension with added

crude LTA (final concn $0.5 \%, \mathrm{w} / \mathrm{v}$ )

FEP films preincubated with crude LTA

$10^{-3} \times$ No. of adhering bacteria $(\mathrm{mm} \text { film })^{-2} \pm$ S.D.

$\begin{array}{cc}\text { FEP } & \text { CA } \\ 24 \pm 6 & 0.6 \pm 0.6 \\ 23 \pm 6 & 1.5 \pm 0.8 \\ 12 \pm 1^{*} & \text { ND } \\ 13 \pm 4^{*} & 0.2 \pm 0.2 \\ 18 \pm 4^{*} & \text { ND }\end{array}$

ND, Not determined.

* Significant $(P<0.001)$ difference between control and test. Other differences were not significant $(P>0 \cdot 2)$.

\section{Table 3. Desorption of bacteria from FEP-fluorocarbon or CA}

The polymer films were incubated with bacterial suspensions in $\mathrm{NaCl} /$ phosphate buffer containing $5 \times$ $10^{8}$ cells $\mathrm{ml}^{-1}$ for $2.5 \mathrm{~h}$ at $37^{\circ} \mathrm{C}$ and rinsed once, eight or sixteen times with $3 \mathrm{ml}$ amounts of buffer. FEP films were also incubated with bacterial suspensions containing $1 \times 10^{9} \mathrm{cells} \mathrm{m}^{-1}$, washed eight times with $3 \mathrm{ml}$ of $\mathrm{NaCl} /$ phosphate buffer and further incubated in enzyme-containing solutions or in a solution of EDTA for $1.5 \mathrm{~h}$ at $37^{\circ} \mathrm{C}$ and then rinsed three times with $\mathrm{NaCl} /$ phosphate buffer. Further details are given in Methods.

$10^{-9} \times$ Initial concn of bacteria incubated with film $\left(\mathrm{ml}^{-1}\right)$

0.5
Bacterial
species

S. epidermidis strain 1

S. saprophyticus

S. epidermidis strain 1
Treatment

Rinsed once

Rinsed eight times

Rinsed sixteen times

Rinsed once

Rinsed eight times

Rinsed sixteen times

Enzyme-free buffer

Trypsin $(0 \cdot 1 \%, \mathrm{w} / \mathrm{v})$

Chymotrypsin $(0 \cdot 1 \%$ w/v)

Pepsin $(0.1 \%, w / v)$

EDTA (20 mM)
$10^{-3} \times$ No. of adhering bacteria $(\mathrm{mm} \text { film })^{-2} \pm$ S.D.

\begin{tabular}{cc}
\hline FEP & CA \\
$15 \pm 3$ & $2 \cdot 7 \pm 1 \cdot 4$ \\
$14 \pm 2$ & $0 \cdot 3 \pm 0 \cdot 3^{*}$ \\
$13 \pm 2$ & $0 \cdot 1 \pm 0 \cdot 1^{*}$ \\
$0 \cdot 5 \pm 0 \cdot 2$ & $0 \cdot 2 \pm 0 \cdot 1$ \\
$0 \cdot 3 \pm 0 \cdot 2$ & $0 \cdot 2 \pm 0 \cdot 1$ \\
$0 \cdot 4 \pm 0 \cdot 2$ & $0 \cdot 2 \pm 0 \cdot 2$ \\
$52 \pm 17+$ & $0 \cdot 6 \pm 0 \cdot 5$ \\
$60 \pm 10$ & ND \\
$61 \pm 11$ & ND \\
$0 \cdot 9 \pm 0 \cdot 2^{*}$ & ND \\
$46 \pm 9$ & ND
\end{tabular}

ND, Not determined.

* Significant $(P<0 \cdot 001)$ difference between control (film washed once, or treatment with enzymefree buffer) and test reactions. Other differences were not significant $(P>0 \cdot 2)$.

$\dagger$ Data obtained by treatment of films with enzyme or EDTA-free $\mathrm{NaCl} /$ phosphate buffer or $\mathrm{NaCl} /$ citrate buffer were used as control and were not significantly different from data obtained with nontreated films.

order to obtain decapsulated bacteria, showed no significantly different adhesion on to either FEP or CA as compared to non-treated cells. In India ink wet-film preparations no decapsulated cells were seen. 


\section{Lipoteichoic acid related effect on adhesion}

Staphylococcus epidermidis strain 2 exposed to $0 \cdot 25$ MIC penicillin to stimulate LTA release, adhered to the same extent on to either FEP or CA as bacteria not exposed to penicillin (Table 2). However, $S$. epidermidis strain 2 obtained after hot aqueous phenol treatment to extract LTA, adhered in lower numbers on to FEP than non-extracted bacteria. Addition of crude LTA to the $S$. epidermidis (strain 2) suspension decreased the bacterial adhesion on to FEP. Crude LTApreincubated FEP films had a lower water contact angle $\left(104^{\circ} \pm 2^{\circ}\right)$ than non-treated films $\left(108^{\circ} \pm 2^{\circ}\right)$. Adhesion of $S$. epidermidis strain 2 on to such LTA-treated films was less than on to untreated FEP films.

\section{Desorption of adhering bacteria}

After frequent rinses, the numbers of $S$. epidermidis strain 1 adhering on to CA decreased significantly, but the numbers of bacteria adhering on to FEP were not reduced. The numbers of $S$. saprophyticus adhering on to either of the polymer films were not lowered after repeated rinses (Table 3).

Pepsin treatment of FEP films with adhering $S$. epidermidis strain 1 resulted in a significant desorption of bacterial cells, whereas trypsin, chymotrypsin or EDTA treatment did not reduce the number of adhering bacteria (Table 3).

\section{DISCUSSION}

The results demonstrated, that the encapsulated strain of Staphylococcus saprophyticus showed a hydrophilic character, as determined by the method of Rosenberg et al. (1980). These cells reaggregated slightly and adhered much less to FEP-fluorocarbon films than those of the two other hydrophobic Staphylococcus epidermidis strains. Staphylococcus epidermidis, rendered less hydrophobic by exposure to pepsin, showed reaggregation patterns and adhesion on to FEP similar to $S$. saprophyticus. These findings suggest that the occurrence of spontaneous reaggregation of staphylococci and their ability to adhere on to the hydrophobic polymer film was related to the presence of hydrophobic cell surface constituents. The mechanism involved in both phenomena might be hydrophobic bonding (Magnussen, 1982; Doyle et al., 1982), although the bacterial reaggregation can also be affected by differences in the bacterial cell surface charge. Adhesion of staphylococci on to the more hydrophilic CA films was always low and not directly related to the bacterial cell surface hydrophobicity.

The cell surface constituents of the staphylococci involved in the adhesion on to the polymers are unknown. Recently, slime produced by $S$. epidermidis was suggested to play a major role in the adhesion of this species on to biomaterial surfaces (Christensen et al., 1982). However, we used non-slime-producing staphylococcal strains. The interaction of Staphylococcus aureus with epithelial cells is reported to be mediated by teichoic acid (Aly et al., 1980). Lipoteichoic acid is thought to be involved in the adhesion of group A streptococci to epithelial cells (Ofek et al., 1975). Staphylococci, deficient in LTA after extraction with hot aqueous phenol showed a decreased adhesion on to FEP suggesting the involvement of LTA in the adhesion process. However, extraction of a staphylococcus and a streptococcus strain with hot aqueous phenol removed only $10 \%$ of their total LTA content (Huff, 1982), whereas constituents other than LTA are also extracted (Silvestri et al., 1978). Therefore, the decrease in hydrophobicity and the reduced adhesion of the extracted cells might be due to the removal of constituents other than LTA or to conformational changes of surface molecules.

Gram-positive bacteria exposed to subinhibitory concentrations of cell-wall active antibiotics are depleted in their LTA or teichoic acid contents (Alkan \& Beachey, 1978; Ramírez-Ronda et al., 1981). In our study, staphylococci exposed to a subinhibitory concentration of penicillin showed no change in their hydrophobicity and adhered on to FEP as did cells not exposed to penicillin, confirming the results obtained by Wadström et al. (1981), who showed that release of LTA did not change the hydrophobicity of staphylococci. Our results indicate that LTA is not a mediator in the adhesion of staphylococci on to FEP, although the adhesion of S. epidermidis on 
to FEP films which has been preincubated with crude LTA extracted from staphylococci was reduced. However, this reduction can be explained by a decreased hydrophobicity of the polymer film as determined by contact angle measurements. Because pepsin treatment of $S$. epidermidis decreased adhesion and caused desorption of adhering staphylococci, it is likely that protein-containing constituents are involved in the interaction of staphylococci with FEP.

The adhesion of a Gram-negative marine Pseudomonas species on to various polymer surfaces was correlated with the polymer surface hydrophobicity (Fletcher \& Loeb, 1979). The number of adhering bacteria increased with increasing hydrophobicity of the polymers tested. Absolom $e t$ al. (1979) reported that surface hydrophobicity (i.e. contact angle) was inadequate as a parameter for the prediction of cellular adhesion on to solid surfaces. They proposed instead that the change in Helmholtz free energy for the overall cellular adhesion process is the appropriate parameter. These authors found that the cell adhesion on to different substrates was also dependent on the surface tension of the liquid medium in which the cells were suspended and the surface tension of the cells. The surface tension of the hydrophobic $S$. epidermidis strain is less than that of the suspending liquid $(\mathrm{NaCl} /$ phosphate buffer). Therefore, our finding that adhesion of $S$. epidermidis on to FEP was greater than to the less hydrophobic CA was in agreement with their results. The surface tension of the more hydrophilic $S$. saprophyticus and of the pepsin-treated or aqueous phenol-extracted $S$. epidermidis might be close to that of the suspending liquid, which could explain the low adhesion of these micro-organisms on to both polymer materials (Hogt et al., 1982).

The adhesion of $S$. epidermidis to FEP showed plateau values related to exposure time and cell concentration, suggesting an equilibrium Langmuir-type adhesion. However, such an equilibrium is only reached if the adhesion of $S$. epidermidis is reversible, which is uncertain. Srinivasan \& Ruckenstein (1981), proposing a kinetic model for the adhesion of cells on to solid surfaces, suggested that the rate of adhesion will be governed by the existing potential energy barriers, provided that the total free energy change for adhesion is negative. Cells interact with a surface via Van der Waals attractive forces and forces associated with electrostatic double layers. The latter are usually repulsive and might generate a substantial energy barrier for adhesion (D.L.V.O.-theory). The plateau values observed in the adhesion of $S$. epidermidis to FEP might be kinetically controlled by the increasing potential energy barrier due to the coverage-induced heterogeneity occurring during the adhesion process. Differences in the rate of reaggregation of the test strains in suspension can also be described using the D.L.V.O.theory (Curtis, 1969). The presence of the hydrophilic capsule in $S$. saprophyticus or the changes in $S$. epidermidis surface constituents due to pepsin treatment or due to extraction with aqueous phenol, might increase the electrostatic repulsion between micro-organisms, thereby limiting the amount of effective collisions and the rate of reaggregation.

Apart from electrostatic and dispersion forces, additional interactions are possible for bacteria in close contact with surfaces (Marshall et al., 1971). Our findings suggest that the adhesion of $S$. epidermidis on to FEP was probably caused by hydrophobic bonding which is not or only slightly affected by the age and the metabolic stage of the bacteria. More studies of this sort with encapsulated and unencapsulated organisms are required before generalizations can be made.

Because after insertion of implants or use of medical devices, most artificial surfaces are rapidly covered by a protein layer (Feijen et al., 1979), the adhesion of staphylococci on to protein-coated polymers is currently being investigated.

This study was supported by a grant from the Netherlands Organization for the Advancement of Pure Research (Z.W.O.).

\section{REFERENCES}

Absolom, D. R., NeumanN, A. W., ZINGG, W. \& vaN Oss, C. J. (1979). Thermodynamic studies of cellular adhesion. Transactions of the American Society for Artificial Internal Organs 25, 152-156.
Adamson, A. W. (1976). Physical Chemistry of Surfaces. New York, London: Wiley-Interscience.

AlkaN, M. L. \& BeacheY, E. H. (1978). Excretion of lipoteichoic acid by group A streptococci. Influence 
of penicillin on excretion and loss of ability to adhere to human oral mucosal cells. Journal of Clinical Investigation 61, 671-677.

Aly, R., Shinefield, H. R., Litz, C. \& MaIbach, H. I. (1980). Role of teichoic acid in the binding of Staphylococcus aureus to nasal epithelial cells. Journal of Infectious Diseases 141, 463-465.

Christensen, G. D., Simpson, W. A., Bisno, A. L. \& BEACHEY, E. H. (1982). Adherence of slime-producing strains of Staphylococcus epidermidis to smooth surfaces. Infection and Immunity 37, 318-326.

Cowan, S. T. \& SteEL, K. J. (1974). Manual for the identification of medical bacteria, 2nd edn, p. 164. Cambridge: Cambridge University Press.

Curtis, A. S. G. (1969). The measurement of cell adhesiveness by an absolute method. Journal of Embryology and Experimental Morphology 22, 305325.

Doyle, R. J., Nesbitt, W. E. \& TAYloR, K. G. (1982). On the mechanism of adherence of Streptococcus sanguis to hydroxylapatite. FEMS Microbiology Letters 15, 1-5.

Duguid, J. P. (1951). The demonstration of bacterial capsules and slime. Journal of Pathology and Bacteriology 62, 673-685.

FAller, A. \& Schleifer, K. H. (1981). Modified oxidase and benzidine test for separation of staphylococci from micrococci. Journal of Clinical Microbiology 13, 1031-1035.

Feijen, J., Beugeling, T., Bantjes, A. \& Smit SibiNGA, C. TH. (1979). Biomaterials and interfacial phenomena. In Advances in Cardiovascular Physics, vol. 3, pp. 100-134. Edited by D. N. Ghista. Basel: S. Karger.

Fisher, R. A. \& Yates, F. (1957). Statistical Methods for Biological, Agricultural and Medical Research. Edinburgh: Oliver \& Boyd.

Fletcher, M. \& LoEb, G. I. (1979). Influence of substratum characteristics on the attachment of a marine Pseudomonad to solid surfaces. Applied and Environmental Microbiology 37, 67-72.

GaRveY, G. (1980). Endovascular and prosthetic implant infections. In Infections in the Abnormal Host, pp. 693-745. Edited by M. H. Grieco. New York: Yorke Medical Books.

hogt, A. H., Feijen, J., Dankert, J. \& de Vries, J. A. (1982). Adhesion of Staphylococcus epidermidis and Staphylococcus saprophyticus on to FEP-teflon and cellulose acetate. In Biomedical Polymers, pp. 39-47. London: Biological Engineering Society.

HoLT, R. J. (1970). Bacteriological studies on colonized ventriculo-atrial shunts. Developmental Medicine and Child Neurology 12 (suppl. 22), 83-87.

HuFF, E. (1982). Lipoteichoic acid, a major amphiphile of Gram-positive bacteria that is not readily extractable. Journal of Bacteriology 149, 399-402.

Kessler, R. E. \& Shockman, G. D. (1979). Precursorproduct relationship of intracellular and extracellular lipoteichoic acids of Streptococcus faecium. Journal of Bacteriology 137, 869-877.

KloOs, W. E. \& Schleifer, K. H. (1975). Simplified scheme for routine identification of human Staphylococcus species. Journal of Clinical Microbiology 1, 8288.
Locci, R., Peters, G. \& Pulverer, G. (1981). Microbial colonization of prosthetic devices. III. Adhesion of staphylococci to lumina of intravenous catheters perfused with bacterial suspensions. Zentralblatt für Bakteriologie, Mikrobiologie und Hygiene (I. Abteilung) 173, 300-307.

MaGNUSSON, K.-E. (1982). Hydrophobic interaction a mechanism of bacterial binding. Scandinavian Journal of Infectious Disease 33 (suppl.) 32-36.

Marshall, K. C., Stout, R. \& Mitchell, R. (1971). Mechanism of the initial events in the sorption of marine bacteria to surfaces. Journal of General Microbiology 68, 337-348.

Moore, W. S., Malone, J. M. \& Keown, K. (1980). Prosthetic arterial graft material. Archives of Surgery 115, 1379-1383.

OFEK, I. \& BeAChEY, E. H. (1980). General concepts and principles of bacterial adherence in animals and man. In Bacterial Adherence. Receptors and Recognition, Series B, vol. 6, pp. 1-31. Edited by E. H. Beachey. London \& New York: Chapman \& Hall.

OfEK, I., BeAChey, E. H. JefFerson, W. \& CAMPBell, G. L. (1975). Cell membrane-binding properties of group A streptococcal lipoteichoic acid. Journal of Experimental Medicine 141, 990-1003.

Ramírez-Ronda, C. H., FuXenCh, Z. \& Hernandéz, N. (1981). Effect of anti-teichoic acid antibody on the adherence of bacterial cells grown in subinhibitory concentrations of penicillin to damaged canine aortic valves. Clinical Research 29, 395A.

RosenberG, M., GutNick, D. \& RosenberG, E. (1980). Adherence of bacteria to hydrocarbons: a simple method for measuring cell-surface hydrophobicity. FEMS Microbiology Letters 9, 29-33.

Silvestri, L. J., Craig, R. A., Ingram, L. O., Hoffmann, E. M. \& Bleiweiss, A. S. (1978). Purification of lipoteichoic acids by using phosphatidyl choline vesicles. Infection and Immunity 22, 107-118.

SRINIVASAN, R. \& Ruckenstein, E. (1981). Kinetically caused saturation in the deposition of particles or cells. Joumal of Colloid and Interface Science 79, 390398.

Stinson, M. W. \& VAN Oss, C. J. (1971). Immunoglobulins as aspecific opsonins II. The influence of specific and aspecific immunoglobulins on the in vitro phagocytosis of noncapsulated, capsulated, and decapsulated bacteria by human neutrophils. Journal of the Reticuloendothelial Society 9, 503-512.

WADSTRÖM, T., HJERTEN, S., JonsSON, P. \& TYLEWSKA, S. (1981). Hydrophobic surface properties of Staphylococcus aureus, Staphylococcus saprophyticus and Streptococcus pyogenes: a comparative study. In Staphylococci and Staphylococcal Infections, Zentralblatt für Bakteriologie, Suppl. 10, pp. 441-447. Edited by J. Jeljaszewicz. Stuttgart: Gustav Fischer Verlag.

WestPhal, O., Lüderitz, O. \& Bister, F. (1952). Über die Extraktion von Bakterien mit Phenol-Wasser. Zeitschrift für Naturforschung, 7b, 148-155.

WiCKen, A. J., Gibbens, J. W. \& KNoX, K. W. (1973). Comparative studies on the isolation of membrane lipoteichoic acid from Lactobacillus fermenti. Journal of Bacteriology 113, 365-372. 